\title{
Succession Issues among Family Entrepreneurs in Countries of the Gulf
}

\author{
Ralph Palliam \\ American University of Kuwait, Safat, Kuwait \\ P.O. Box 3323, Safat 13034, Kuwait \\ Tel: +965-2224-8399 ext. $419 \quad$ Fax: +965-2572-9638Ｅ-mail: r.palliam@auk.edu.kw \\ Hanas A. Cader (Corresponding author) \\ American University of Kuwait, Safat, Kuwait \\ P.O. Box 3323, Safat 13034, Kuwait \\ Tel: +965-2224-8399 ext. $572 \quad$ Fax: +965-2572-9638Ｅ-mail: mcader@auk.edu.kw \\ Charles Chiemeke \\ American University of Kuwait, Safat, Kuwait \\ P.O. Box Palliam 3323, Safat 13034, Kuwait \\ Tel: +965-2224-8399 ext. $562 \quad$ Fax: +96525729638Ｅ-mail: cchiemeke@auk.edu.kw
}

Received: January 28, 2011 Accepted: February 18, 2011 doi:10.5430/ijba.v2n2p25

\begin{abstract}
Small family business succession is gaining increased prominence in Western societies. In Arab societies, literature on family business succession is virtually nonexistent. As Arab societies are embracing Western values, the issues of family business succession that are considered in the West will become major issues in Arab societies. This empirical study explores the transferability of theoretical constructs developed in the West to the countries of the Gulf Cooperation Council. The findings suggest that a family enterprise that has decided to keep management control within the family cannot possibly hope to achieve this without family members who are trusted by the incumbent.
\end{abstract}

Keywords: Succession, Family business, Culture, Arab entrepreneurs

\section{Introduction}

A large number of family enterprises pervade the six countries of the Gulf Cooperation Council (GCC). Moreover, these families have excelled over the years in passing skills and knowledge to their children, reaffirming the work ethic and entrepreneurial spirit that have made Arabs entrepreneurs highly successful throughout the world. Many Arab entrepreneurs are perceived not to be able to imagine life without the responsibilities of managing the family enterprise because their working lives have revolved entirely around their enterprise, leaving little time to develop outside interests. Sharma, Chua, and Chrisman (2000) in their seminal work: "Perceptions about the extent of succession planning in Canadian family firms" adopt the same trend of thought. Whether the tradition still thrives has not been a subject of intense debate and research particularly in the GCC States is lacking This perhaps is a result of the culture of the family where family members are not comfortable discussing topics such as aging, death, and their financial affairs (Ward, 1987). Moreover, issues such as who is going to manage the business when one no longer works in the business; how will ownership be transferred; will one's business even carry on or will one sell it are not openly discussed. However, cultural, economical and social transformations in the GCC States will lead to a new demography, as well as to different family arrangements, which will affect the way succession in family enterprises are viewed. Murphy (2005) contends that dealing effectively with the issue of succession planning is the single most lasting gift that one generation can bestow on the next. 
Sharma, Chrisman and Chua (1997) list a variety of studies which examine the subject of management succession in small enterprises in the United States. Many other studies have previously been undertaken in other Western societies and are cited by Boissevian and Hanneke (1987) and Sease and Goffe (1987) in their research studies: "Entrepreneurship in Europe". One issue that is central to the findings of these studies is that many successful entrepreneurs have a strong desire to have the future of their enterprises perpetuated. Nelton (1988) contend that ensuring perpetuation is often difficult and at times the transition is seldom smooth since the leading figure in the family often finds it difficult to "let go".

Several authors, amongst whom one can include Poza, Alfred and Maheshwari (1997) and Chua, Chrisman, and Steier, (2003) have alluded that succession in a family business is probably the most complex management challenge anybody faces. Certain emotional issues arise which often require changes in the structure and culture of the organization as well as changes in the people involved particularly if the entrepreneurs, as Bullock (1978) describes them as having a sizeable ego and typically are "workaholics" and often think that they will last forever Ambrose 1983 and Jones and Nisbett (1971) found that there is psychological resistance to the thought of dying or being incapacitated. Entrepreneurs harbor a number of myths about problems preventing resolution of succession, and there some real limitations to the ability of a small enterprises to handle this problem which results from its small scale operations and restricted ownership. Initiating the process of letting go, forces the incumbents to face their mortality and confront the prospect of changes in their lives after succession. In general researchers tend to agree that the transfer power from the first generation to the second rarely takes place while the founder is alive and on the scene (Dyer, 2003). What occurs is a transition period of great difficulty for both the older and the younger generations. Ambrose (1983) found that certain factors tend to inhibit and other factors tend to encourage effective transfer of family-owned businesses.

Succession planning in the family enterprise is the explicit process by which management control is transferred from one family member to another. Researchers in the West have long stressed succession planning's importance in ensuring the continuity and prosperity of a business (Christensen, 1953; Trow, 1961; Ward, 1987, Dyer, 2003) because it is undeniable that the sudden departure of the family enterprise leader can cause major upheavals in the exercise of power and authority, precipitate conflict among heirs and potential successors, and raise thorny estate issues (Christensen, 1953; Lane, 1989). There are several ways in which an entrepreneur can exit or retire from the business. In situations where the business continues to operate, the main forms of ownership transfer are through family succession, employee succession or the sale of the business to someone outside of the existing enterprise structure. An alternative to succession is business closure, where the exiting entrepreneur may be able to realise some of the capital and goodwill.

Within this context it is paramount to establish an understanding of the succession processes used in family enterprises particularly in the GCC States that manifests very different demographic trends as compared to the West. It is also important to understand the factors that influence the approaches taken to succession planning in the GCC States. Is succession planning attempted or not? What particular approaches are adopted and favored or disfavored? What are the perspectives of the key stakeholders in the Arab family? Business succession planning seeks to manage these issues, setting up a smooth transition between the current entrepreneur and the successor. This includes: selecting the successor, training the successor, communicating the decision, developing the business plan for the enterprise after succession, and defining the long-term future role of the departing incumbent.

In general the extent to which a family enterprise engages in succession planning is positively affected by the propensity of the incumbent to step aside and particularly the presence of a competent successor. As early as 1953 Christensen suggested that as part of succession planning, the family enterprise must identify a pool of potential successors, specify the criteria, designate the successor, and communicate the decision to the successor designate and all other stakeholders. Lansberg (1988) and Ward (1987) added successor training and formulation of a post-succession business strategy to the list. However, an important issue that should not be overlooked is that succession planning must also include a clarification of the role, responsibilities, and ownership stake of the incumbent after succession. This is particularly important in patriarchical societies where fathers have supreme authority within families and male members of a society tend to predominate in positions of power. Arab societies dramatically manifest a patriarchal ideology which is upheld and reinforced through male-governed social and legal institutions. The more powerful the position, the more likely it is that a male will hold that position. Incumbents in the Arab family enterprises typically spend a large proportion of their lives building and running their business, leaving little time to develop interests outside the business and family. Davis (1982) and Sonnenfeld and Spence (1989) noted that in the first few years after succession incumbents found financial resources of their enterprises often remain affected by their enterprise's performance, making many such leaders more than willing to step in at the first sign of trouble. Successors often found that the departing incumbent will continue to be involved, if not actively in the business, at least as a senior family member. Clarification of role, responsibilities, and ownership stakes may give successors the time they need to establish their credibility and independence in the business. 
Similar studies of strategic planning by Murphy (2005), Wu (1983), Barnes and Hershon (1976) suggest that family business researchers believe that succession planning is largely dependent upon the support of the incumbent family entreprise leader. Undoubtedly, the indications are that the incumbent's supreme control over the enterprise makes these incumbents to delay succession planning and thereby becoming the greatest single barrier to succession. Incumbents may resist succession planning for lifestyle, psychological, and behavioural reasons. Implementing the process also requires incumbents to learn how to coach and plan rather than do the job themselves. This means letting others make mistakes so that they can learn from those mistakes. It also means accepting that others can do things differently and still be effective. Consequently, if an incumbent decides to step aside, a major impediment would be removed and the likelihood of planning for succession should be higher than if incumbent has not yet decided to retire. Thus, the above arguments lead to the hypothesis that the propensity of the incumbent to step aside will lead to a higher extent of succession planning. Too often entrepreneurs spend years building a business and come to an agreement with a family member over succession, but fail to make plans to finance the succession. A plan that was appropriate when one commences a business, years ago may not be as suitable today.

\section{Culture, Entrepreneurship and Succession}

Muslims in Arab societies believe that Islam gives guidance to all aspects of life including the law of succession so that each eligible person gets the due share. Although the distribution of inheritance and succession are important topics for many, studies on this subject are scarcely found. Shapero (1982) concluded that culture was an explanatory variable for entrepreneurial activity or the lack of it. He also noted that some cultures value entrepreneurship more than others do. In discussing Arab entrepreneurs what bearing has culture, in particular religion and religious teaching have on business attitudes among the entrepreneurs? In this regard Kamali (1997) noted that the principle tenet of Islam is that 'God helps he who works hard'. Religious values in Islam may cause entrepreneurs to be looked up to, or down upon, depending on the beliefs of people and their prominent moral code of behavior. Arab entrepreneurs tend to have a high propensity to save and reinvest business earnings; a universally strong desire to secure a better education for their children who would then be expected to carry on the business. They also have a strong sense of loyalty and mutual obligation within the extended Arab family. In essence, the Weberian approach argues that entrepreneurial behavior is culturally influenced by values, beliefs, and disbeliefs. According to Weber (1905), religion, the caste system, and the family system affected the emergence of entrepreneurship in India. Along the same theme, Gadgil (1959) showed that Muslims were the chief traders in many parts of the Middle East and the sub-continent. An empirical study by Enz, Dollinger, and Daily (1990), finding different value orientations among different groups, concluded that value orientation may be an important component in ethnic enterprise. Some cultures simply value entrepreneurial activity more than others. This is evident in the GCC States.

Despite a plethora of references to Islam, very few can be found concerning the management of small businesses in the Arab society. Answers to questions like, who makes decisions, what constitutes a good manager, and how decisions should be coordinated seem to be most based on anecdotal evidence. Moreover, very little is known of how Arabs continue with a business beyond one generation of leaders. The issue is further exacerbated by the influence of Arab culture and business conduct where individuals have the freedom to make decisions only within the fixed and eternal set of orders coming from God (Kamali,1997). Moreover, the freedom of choice of the consumer and the producer is restricted and conditioned by not only the obligations but also the recommendations of Islam's elaborate value system. Within the constraints of these values and commands that are imposed, Islamic governments seek to attain the economic objectives of the system. Government intervention in the market is encouraged under specific circumstances. It can be argued that perfect competition, operating through its own self-adjusting automatic mechanisms, constitutes the primary coordinating mechanism of the Islamic economic system, providing it fulfils the Islamic system's first-order priorities. Islam prohibits price fixing by buyers or sellers and encourages exchange in a market characterized by numerous buyers and sellers in which none possesses a controlling share. A general consensus exists that profit making does constitute a feature of the Islamic economic system since there are no restrictions on profits. The market of Islam is characterized by free information and free of discrimination. Producers are expected to inform consumers of the quality and quantity of the goods they claim to be selling, in return for the consumers' payment of the market price. In the Islamic market, therefore, cheating or short-changing consumers, committing any type of fraud, or the exercise of any type of sellers' preference, as well as the payment of bribes, are prohibited.

Essentially, Islamic values have implications both for individual and collective economic behaviour. Economic as well as non-economic values, norms and codes are inscribed in the Shari'ah Islamiyah commonly refereed to as Islamic Law. According to Kamali (1989:215), the Shari'ah "refers to commands, prohibitions, guidance and the principles that God has addressed to mankind pertaining to their conduct in this world and salvation in the next". This value system is gradually passed on from one generation to another. Moreover, wealth should be circulated widely and not held or 
concentrated in a few. To encourage circulation of wealth, the Shari'ah encourages trade. The Shari'ah encourages commutative sales contracts and thus encourages the attainment of a monetised economy rather than barter. On the redistributive side, the Shari'ah also institutes Zakat. It is a religious tax based on wealth or income depending on the category of wealth. It is obligatory on all Muslims who possess wealth beyond a fixed minimum and hold it for at least one calendar year. The Islamic State collects it, in the absence of which individuals are obliged to pay it on their own to the beneficiaries designated by the Qur'an (poor, indigent, travellers, bankrupt, zakat collectors, to liberate slaves or oppressed people and "in the way of God". Traditionally, Zakat is only payable on gold and silver (and by extension money), business inventory and profits, livestock and farming output of staple food crops. Its basic rate is $2.5 \%$ but in case of agricultural output it is $5 \%$ or $10 \%$ depending on whether the land is irrigated naturally or otherwise. Zakat on cash and savings at $2.5 \%$ of value acts as a disincentive to holding wealth in a zero interest environment. In addition to Zakat, sadaqah (voluntary charity) and waqf (endowments) are encouraged.

Kamali (1997) further notes that hoarding and monopolies (except state monopolies) are not allowed in Islam. The giving of just measure for measure is essential and a whole institution (the Hisba) pertaining to just weights and measures and surveillance of market activities to root out fraud has been part of Islamic economy for a long time. There is also an elaborate law of succession in the Qur'an. The Shari'ah has specified the beneficiaries of an estate together with their shares rather than allowing the testator to do as he wishes. This stipulation seeks to redistribute property to the nearest relatives of the deceased in a fair manner so that the deceased cannot will away the property to others while leaving his children to poverty.

\subsection{Succession}

According to Westhead and Cowling (2002) business succession processes have significant implications from an economic perspective. Succession enables the incumbent to realise some of the capital built up in the enterprise, which can then be used to finance the retirement. For family members and employees (potential owners), succession provides a career path in an enterprise or sector that may otherwise have limited opportunities for career advancement. If succession is planned, then there could be mutual benefits to both parties through a staged succession, which reinforces the opportunities for both parties to achieve their goals with respect to career advancement and retirement. Thus, succession is an important long-term strategic consideration in Arab societies where self employment in small business is a dominant form of employment or business structure. From a business development perspective, ownership succession can be seen as critical to the long-term nature of businesses ownership in Arab societies and thus has implications relating to the form of support that is required in the small business environment.

The main options in terms of succession include variations of the following: family succession; employee succession; sale of business; or business closure. Family succession remains the dominant form of transferring business ownership in the Arab societies. Employee succession practices are non existent in Arab societies which tend to have very little established mechanisms for allocating capital/equity in the business to facilitate the exit and entry of people at the ownership or partnership level. The level of mobility or turnover of employees in small businesses in these societies is extremely high. Much of the labour force is expatriate population and for whom very little or no planning is instituted.

\section{Nature and Method of study}

This study was undertaken over a period of eight years commencing in December 2000. Senior students who were registered for the financial statements analysis course, a core requirement for the Bachelor of Business Administration at the American University of Sharjah, conducted the field work. Prior to any field work taking place, several focus group discussions were held with students outlining the purpose of the study, the methodology and the nature of interviewing. Moreover, preliminary discussions with the students revealed certain misconceptions and thoughts surrounding succession issues in Arab societies. Although 102 students volunteered to be the fieldworkers only 57 became the fieldworkers. The student fieldworkers were all indigenous to the Gulf States and some have continued to collect data over the period of eight years communicating them electronically. The data collection included, inter alia, the monitoring, if any, of the process of succession in the six Gulf States over the period and this becomes a further study in this area. Data were obtained from 251 incumbent entrepreneurs. However, 29 were not suitable for use.

Since the data required were of a somewhat sensitive nature, the fieldworkers needed to be indigenous to the area, know the culture of the region very well and were well advised to form a very close relationships with the incumbent in order that the monitoring process of succession could be obtained. Moreover, the fieldworkers were advised by other students not to devalue the worth of the incumbent by ridiculing any practices that are not consistent with modern practices. Fieldworkers were sensitive to several issues and were advised to win the trust and confidence of the incumbent. Data constantly coming through from a large number of fieldworkers suggest that many fieldworkers have enlisted the incumbents as clients. 


\section{Formulation of Hypothesis}

Based upon the preceding literature survey and the findings of the focus group discussions, the following hypotheses were developed:

$H_{1}$ : There is a strong positive correlation between the willingness (propensity) of the incumbent to let go (Y) and the age of the owner $\left(X_{1}\right)$.

$H_{2:}$ There is a strong positive correlation between the willingness (propensity) of the incumbent to let go (Y) and the age of the potential successor $\left(X_{2}\right)$.

$H_{3:}$ There is a strong positive correlation between the willingness (propensity) of the incumbent to let go (Y) and the number of competent successors $\left(X_{3}\right)$.

$H_{4:}$ There is a strong positive correlation between the willingness (propensity) of the incumbent to let go (Y) and the number of years that the incumbent held the position $\left(X_{4}\right)$.

$H_{5:}$ There is a strong positive correlation between the willingness (propensity) of the incumbent to let go (Y) and the willingness of the potential successor to step in $\left(X_{5}\right)$.

$H_{6:}$ There is a strong positive correlation between the willingness (propensity) of the incumbent to let go (Y) and the education level of the prospective successor $\left(X_{6}\right)$.

$H_{7:}$ There is a strong negative correlation between the willingness (propensity) of the incumbent to let go (Y) and unhealthy financial metrics $\left(X_{7}\right)$.

The dependent variable $(Y)$ for study is the willingness or the propensity of the incumbent to let go of the business. This was measured using the following scale:

$<$ Table 1 about here $>$

The class midpoints $0,25,50,75$ and 100 were used to measure the propensity of the incumbent to let go. In order to examine the impact of explanatory variables on the propensity of the incumbent to go, the response variable $\mathrm{Y}$ has the limits from 0 to 100. The Ordinary Least Square (OLS) estimates as censored models are commonly used when the independent variable is constrained to range, having upper and lower bound values. The Tobit model which is one form of the censured models is used in this analysis. Glauben et al., (2002) have used the Tobit model to examine the impact of family farm and characteristics on the succession of the farm businesses in Australia. The Tobit model is a probability model, where one estimates the probability of observing estimate marginal effects. In the analysis an estimate of the marginal effects of the Tobit model is made. This measures the one unit increase in the mean of explanatory variable the propensity of the incumbent to go.

\section{Findings}

A total of 222 were included in the analysis. Table 2 shows the descriptive statistics of the data and the correlation between explanatory variables (willingness or propensity of the incumbent to let go) and response variables. The table shows that there is a strong positive correlation between the numbers of potential successors, the number of years of schooling of the incumbent and the propensity to let go. Moreover, the older the incumbent and the longer the incumbent was in business, the greater is the willingness or propensity of the incumbent to let go. There is a negative correlation between debt to equity ratio and the propensity of the incumbent to let go. This may be due to the influence of cultural and religious values, where the incumbents are less likely to have debt and in the case of having debt, there are less likely to transfers it to the next generation. The data also suggest a weaker positive correlation between willingness of potential successor to step and propensity of the incumbent to let go. Surprisingly the data also indicate that there is a negative correlation is associated with the education level of the incumbent and the response variable. The negative correlation confirms the business owners perception about the on the job training and formal business education, the perception is more favorable to on the job training to the success of family business. Further, the interviewers noted that some of business owners consider the formal business education as a hindrance to the growth and development of the family business.

$<$ Table 2 about here $>$

\subsection{Empirical Findings}

The Tobit model was estimated using Limdep (2009) software. The Limdep software has the provision to estimate a model for data having response variable that is censored with upper and lower bounded values. The estimated coefficients and their marginal effects are presented in Table 3. Except the age of the owner and educational levels of the successor, all the other variables were significant at 5 percent level. The relationship between the age of the incumbent 
and willingness of the incumbent to let it go is negative and not significant. Thus, the first hypothesis 'strong positive correlation between the willingness (propensity) of the incumbent to let go and the age of the owner is unsubstantiated. Similarly, there is no evidence to support the hypothesis that there is a strong positive correlation between the willingness (propensity) of the incumbent to let go and the business education level of the prospective successor, as the relationship is negative and insignificant. The result indicates that in family businesses formal education is not likely be valued as much as corporate business, implying that incumbent expects the successor to have more on the job training rather than in-class education. In a related literature, Dyke et al., (1992) found that there is no correlation between formal education and performance of the family business. Specific human capital development can be achieved through on the job training or functional experiences, which are more valuable and specific to the organizations (Becker, 1993).

$<$ Table 3 about here $>$

There is a negative and significant relationship between the age of the potential successor and the willingness of the incumbent to let go. The results show that the incumbent prefers the successor step-in to run the family businesses as early as possible. The young ones are considered to be relatively more productive and as potential successors can contribute more to the business. In this regard, García et al., (2002) in considering "the reproductive socialization model" found that the incumbent prefers the successor to step-in at an early age and would like to "clone" the successor to begin his/her career from shop floor to managerial positions (García \& Lópezs, 2006:245). This could be partly due to the nature of the business, where the family businesses are considered to be highly idiosyncratic (Williamson, 1979; Lee et al., 2003). The coefficient for number of competent successors is positive and significant, which indicate larger the pool of the competent successors higher the likelihood of the incumbent to let it go. Interestingly, Castanias and Helfat (1991 \& 1992) found that idiosyncratic knowledge of family businesses is mostly individual specific, hence a larger pool of potential successors increases the possibility of finding good successors. As a result the incumbent may prefer the successor to step-in early for the successor to identify and familiarize himself/herself with the idiosyncrasies of the firm (Barach et al., 1988). The early step-in of the successor may facilitate the incumbent to transfer the idiosyncratic nature of the family business knowledge and learning by doing.

The coefficient for number of years incumbent is in business is positive. The longer the incumbent stays in the business the more the opportunity for learning. Early step-in and longer time stay in the firm may give the successor an adequate amount of time to accumulate necessary knowledge and perhaps to obtain the confidence of the incumbent and the rest of the family to operate on his/her own. The planning and intersession of the transformation of the family business ownership between two generations starts early as five years and take up-to twenty years (Schulman, 1991; Zaudtke \& Ammerman, 1997). An early step-in by the successor may give adequate time to get the necessary experience to obtain competency to run the business independently. Further, an early succession process (grooming) may reduce the likelihood of the family business succession failures (Fiegener et. al., 1996).

The coefficient for the willingness of the successor to step in is negative and significant. The incumbent may feel that a successor's willingness to entry would question the ability of the incumbent to run the business successfully. In the patriarchal societies such as in the Middle East the head of the businesses are figure-heads as well. The figure-head is assumed to be the one possessing knowledge and competency to run the business successfully. An individual's ability which is "exogenous, defines the individual's competency as head of the business" (Lee et al., 2003, P.657). The traditional norms and the cultural practices tend to respect the elders and successors are expected to respect these traditions. The successor's willingness to enter the business might also demonstrate that the successor is opportunistic. Although, this trait is considered as a positive behavior in the entrepreneurship behavior, in a family is business it decrease the chances of an individual's business succession. Although, some researchers have found the individual family members to show some opportunistic behavior (Ling et al., 2001), other's have found that the family successor's are found to be less opportunistic (Klein et al., 1978). In a related literature, Pollack (1985: p. 590) found that "both family loyalty and cultural norms limit opportunistic behavior" and the individuals may be expelled from the family (Akerlof, 1980).

The debt to equity ratio has a negative and significant impact on the likelihood of the incumbent to let it go. Interestingly, in many occasions the succession takes place when the incumbent is not performing well in the business, having higher debt to equity ratio, having a positive coefficient. The negative sign indicates that the incumbent is less likely to transfer the ownership with a higher debt. This is very much influenced by the cultural and religious values in the society. Having debt is considered to be unworthy and transferring it to a successor is immoral. The incumbent's usually have built their family businesses primarily from their own wealth and are more inclined to safeguard their investments. The debt is likely to increase the risk of failure and it may have negative effect on the incumbent's personal wealth (Schulze 
et al., 2003). Reid et al., (1999) found that family firms are reluctant to seek debt financing as it may lead to dilution of family control, while De Massis et al., (2008) reported that the incumbent's debt may exert a considerable strain on family resources and which may lead to failure of the succession. Further, transferring debt may create disputes between family business successors and creditors (Basly, 2007), hence the incumbent more likely to avoid transferring debt to the successor.

\section{Conclusion}

Entrepreneurial activity, self-employment and business ownership results in a significant contribution to economic activity in the GCC States. Succession is therefore an important long-term strategic consideration in sectors where self-employment in family business is a dominant form of employment or business structure. From a business development perspective, succession can be seen as critical to the long-term nature of businesses ownership and thus has implications relating to the form of support that is required in the small business environment. The decision of an Arab entrepreneur in the GCC to start planning for succession is likely to be influenced more by the following variables: age of the potential successor, number of competent successors, number of years the incumbent is in business, willingness of the successor to step in and the debt to equity ratio which reflects the financial health of the business. The conclusion drawn from the study is that succession planning is generally not being performed. Arab entrepreneurs have fears about their enterprises' future and have elected not to address these issues. It is likely that many incumbents participating in this study, will continue to operate on an ad hoc basis until some major event forces them into making last-minute choices. Potential successors who have acquired higher education tend not to be willing to move into the family business. Moreover, the willingness of potential successors to step in was considerably lower than the willingness of the incumbent to let go. After ownership changes hands, the responsibility for most aspects of management ought to pass to the successor. However, in patriarchal societies like the GCC States the father is likely to provide advice and retain a dominating role while he is physically able to do so. The study noted that this tendency was considered by Arab entrepreneurs as a mechanism ensuring potential successors' continuity of the business as well as providing on-going income for the retiring incumbent. The key steps in the overall process of succession planning involves the identification of a potential successor early on, and the development and agreement of a staged succession process over an apprenticeship period particularly when career goals of the successor and retirement needs of the incumbent become more pressing. Since family inheritance will continue to be the dominant form of succession in the GCC States, an interesting point for further study would also be the impact of the higher standard of Western education among Arab families as well as the different life-style expectations of the younger generation on the family entrepreneurial values and modus operandi. An equally important challenge will also entail the development of proper training and consultancy services rooted in the culture of the region.

\section{References}

Akerlof, G. A. (1980). A theory of social customs, of which unemployment may be one consequence. Quarterly Journal of Economics, 94, 749-772. doi:10.2307/1885667, http://dx.doi.org/10.2307/1885667

Ambrose, D. (1983). Transfer of the Family-owned Business. Journal of Small Business $\quad$ Management, 21(1,: 49-56.

Barach, J. A., Gantisky, J., Carson, J.A., \& Doochin, B. A. (1988). Entry of the Next Generation: Strategic Challenge for Family Business. Journal of Small Business Management, 26(2): 49-56.

Barnes, L., \& Hershon, S. (1976). Transferring Power in the Family Business. Harvard Business Review, 53(4), 105-114.

Basly, S. (2007). Conservatism: an explanation of the financial choices of the small and medium family enterprise. Corporate ownership and control, 5(1), 459-469.

Becker, G. S. (1993). Human Capital: A Theoretical and Empirical Analysis with Special Reference to Education ( $3^{\text {rd }}$ ed.). University of Chicago Press: Chicago, Illinois.

Boissevain, J., \& Hanneke, G. (1987). Ethnic Enterprise in the Netherlands: The Surinamese of Amsterdam, Entrepreneurship in Europe: In Goffee, R., \& Scase, R. (Eds.), The Social Process (pp. 105-130), London, Croom Helm.

Bullock, J. (1978). Problems of Succession in Small Business. Human Resource Management, 17(2), 2-6.

Castanias, R. P., \& Helfat, C. E. (1991). Managerial resources and rents. Journal of Management, 17, 155-171. doi:10.1177/014920639101700110, http://dx.doi.org/10.1177/014920639101700110 
Castanias, R. P., \& Helfat, C. E. (1992). Managerial and windfall rents in the market for corporate control. Journal of Economic Behavior and Organization, 18(2), 153-184. doi:10.1016/0167-2681(92)90025-7, http://dx.doi.org/10.1016/0167-2681(92)90025-7

Chua, J., Chrisman, J., \& Steier, L. (2003). Extending the Theoretical Horizons of family Entrepreneurship Theory and Practice, 27, 331-338. doi:10.1111/1540-8520.00012, http://dx.doi.org/10.1111/1540-8520.00012

Davis, J. A. (1982). The influence of life-stage on father-son work relationships in family dissertation). Harvard Business School.

Business Research.

companies. (Doctoral

De Massis, A., Chua, J.H., \& Chrisman, J.J. (2008). Factors preventing intra-family succession. Family Business Review, 21(2), 183-199. doi:10.1111/j.1741-6248.2008.00118.x, http://dx.doi.org/10.1111/j.1741-6248.2008.00118.x

Dyer, W. G. (2003). The family: the missing variable in organizational research. Entrepreneurship Theory and Practice, 27(4), 401-416. doi:10.1111/1540-8520.00018, http://dx.doi.org/10.1111/1540-8520.00018

Dyke, L. S., Fischer, E.M., \& Reuber, A.R. (1992). An Inter-Industry Examination of the Impact of Owner Experience on Firm Performance. Journal of Small Business Management, 30(4), 72-87.

Enz, C. A., Dollinger, M. J., \& Daily, C. M. (1990). The Value Orientations of Minority and Non-Minority Small Business Owners. Entrepreneurship, Theory and Practice, 15(1), 23-35.

Fiegener, M. K., Brown, B.M., Prince, R.A., \& File, K.M. (1996). Passing on Strategic Vision: Favored Modes of Successor Preparation by CEOs of Family and Nonfamily Firms. Journal of Small Business Management, 34(3), $15-26$.

Gadgil, D, R. (1959). Origins of the Modern Indian Business Class. New York, N.Y.: Institute of Pacific Relations.

García-Álvarez, E., \& López-Sintas, J. (2006). Founder-Successor's Transition: A Model of Coherent Value Transmission Paths, In P. Poutziouris, K. Smyrnios, \& S. Klein, (Eds.). Handbook off Research on Family Business (pp. 237-251), Edward Elgar Publishing, U.S.

García-Álvarez, E., Sintas, J., \& Saldaña Gonzalvo, P. (2002). Socialization Patterns of Successors in First- to Second-Generation Family Businesses. Family Business Review, 15(3), 189-203.

Jones, E. E., \& Nisbett, R. E. (1971). The actor and the observer: Divergent perceptions of the causes of behavior. Morristown, New Jersey: General learning press.

Kamali, M. H. (1989). Source, Nature and Objectives of Shariah. The Islamic Quarterly, 33 (4), 215-235.

Kamali, M. H. (1997). Maqasid Al-Shari'ah: the Objectives of Islamic Law, Unpublished, Paper presented at the 1st Symposium on Islamic Law and the West, Leicester, UK: The Islamic Foundation.

Klein, B., Crawford, R. G., \& Alchian, A. A. (1978). Vertical integration, appropriable rents, and the competitive contracting process. Journal of Law and Economics, 21, 297-326. doi:10.1086/466922, http://dx.doi.org/10.1086/466922

Lane, S. H. (1989). An organizational development/team building approach to consultation with family businesses. Family Business Review, 2(1): 5-16. doi:10.1111/j.1741-6248.1989.00005.x, http://dx.doi.org/10.1111/j.1741-6248.1989.00005.x

Lansberg, I. (1988). The succession conspiracy. Family Business Review, 1(2), 119-143. doi:10.1111/j.1741-6248.1988.00119.x, http://dx.doi.org/10.1111/j.1741-6248.1988.00119.x

Lansberg, I., \& Astrachan, J. H. (1994). Influence of family relationships on succession planning and training: The importance of mediating factors. Family Business Review, 7(1), 39-59. doi:10.1111/j.1741-6248.1994.00039.x, http://dx.doi.org/10.1111/j.1741-6248.1994.00039.x

Lee, D. S., Lim, G. H., \& Lim,W. S. (2003). Family business succession: Appropriation risk and choice of successor. Academy of Management Review, 28(4), 657-666.

Ling, Y., Lubatkin, M., \& Schulze, B. (2002). Altruism, utility functions and agency problems at family firm. In C.S. Galbraith (Eds.), Volume 3: Strategies and organizations in transition (pp. 171-188), Kidlington, UK: Elsevier Science Ltd. 
Malinen, P. (2001). Like father like son? Small family business succession problems in Finland. Enterprise and Innovation Management Studies, 2 (3), 195-204. doi:10.1080/14632440110105053, http://dx.doi.org/10.1080/14632440110105053

McClendon, R., \& Kadis, L. (2004). Reconciling Relationships and Preserving the Family Business, Binghamton, NY: Haworth

Murphy, D. L. (2005). Understanding the complexities of private family enterprises: An empirical investigation. Family Business Review, 18(2), 123-133. doi:10.1111/j.1741-6248.2005.00036.x, http://dx.doi.org/10.1111/j.1741-6248.2005.00036.x

Nelton, S. (1988). Making Sure Your Business Outlasts You. Nation's Business, 32 (January): 32-38.

Pollak, R. A. (1985). A transaction cost approach to families and households. Journal of Economic Literature, 23, 581-608.

Poza, E. J., Alfred, T., \& Maheshwari, A. (1997). Stakeholders perceptions of culture and management practices in family and family enterprises: A preliminary report. Family Business Review, 10(2), 135-155. doi:10.1111/j.1741-6248.1997.00135.x, http://dx.doi.org/10.1111/j.1741-6248.1997.00135.x

Reid, R., Dunn, B., Cromie, S., \& Adams, J. (1999). Family Orientation in family firms: A model and some empirical evidence. Journal of Small Business and Enterprise Development, 6 (1), 55-66. doi:10.1108/EUM0000000006668, http://dx.doi.org/10.1108/EUM0000000006668

Schulman, M. G. (1991). Successful Succession Planning. CA Magazine, July, 43-45.

Schulze, W.S., Lubatkin, M.H. \& Dino, R.N. (2003). Exploring the agency consequences of ownership dispersion among the directors of private family firms. Academy of Management Journal, 46 (2), 179-194. doi:10.2307/30040613, http://dx.doi.org/10.2307/30040613

Shanker, M. C., \& Astrachan, J. H, (1996). Myths and realities: Family business's contribution to the U.S. economy - A framework for assessing family business statistics. Family Business Review, 9(2), 107-123. doi:10.1111/j.1741-6248.1996.00107.x, http://dx.doi.org/10.1111/j.1741-6248.1996.00107.x

Shapero, A. (1984). The Entrepreneurial Event, The Environment for Entrepreneurship, $\quad$ 21-40.

Shapero, A. \& Sokol, L. (1982). The Social Dimensions of Entrepreneurship, In C. A. Kent, D. L. Sexton, \& K. H. Vesper (Eds.). Encyclopedia of Entrepreneurship, (pp 72-90), Englewood Cliffs, New Jersey, Prentice Hall.

Sharma, P., Chrisman, J. J., \& Chua, J. H. (1997). A review and annotated bibliography of the family business literature. Boston: Kluwer.

Sonnenfeld, J. (1986). Heroes in collision: Chief executive retirement and the parade of future leaders. Human Resource Management, 25(2), 305-333. doi:10.1002/hrm.3930250209, http://dx.doi.org/10.1002/hrm.3930250209

Scase, R., \& Goeffee, R. (1987). Ethnic Entrepreneurs in Britain and in Europe, In R. Goffee, \& R. Scase (Eds.). Entrepreneurship in Europe (83-104), London: Croom Helm.

Trow, D. B. (1961). Executive succession in small companies. Administrative Science Quarterly, 228-239. doi:10.2307/2390756, http://dx.doi.org/10.2307/2390756

Ward, J. L. (1987). Keeping the family business healthy: How to plan for continuing growth, profitability, and family leadership. San Francisco: Jossey-Bass.

Weber, M. (1905). The Protestant Ethic and the Spirit of Capitalism, translated by Talcott Parsons. London: G. Allen and Unwin; New York: Scribner and Sons.

Westhead, P. C., \& Cowling, M. (2002). Ownership and management issues in first generation and multi-generation family enterprises. Entrepreneurship and Regional Development, 14, 247-269. doi:10.1080/08985620110112088, http://dx.doi.org/10.1080/08985620110112088

Williamson, O. E. (1979). Transaction-cost economics: The governance of contractual relations. Journal of Law and Economics, 22, 223-261. doi:10.1086/466942, http://dx.doi.org/10.1086/466942

Wu, Y. L. (1983). The Role of Alien Entrepreneurs in Economic Development: An Entrepreneurial Problem. American Economic Review, 73(2): 112-117.

Zaudtke, D., \& Ammerman, D. (1997). Family business: The next generation. Management Review, 86, 54-57. 
Table 1. Measurement Scale for the Propensity of Incumbent to Let Go and the Class Midpoints

\begin{tabular}{|l|c|c|}
\hline & $\begin{array}{c}\text { Propensity of } \\
\text { incumbent to let go }\end{array}$ & $\begin{array}{c}\text { Class } \\
\text { midpoints }\end{array}$ \\
\hline Totally unwilling to let go & 0 & 0 \\
\hline Totally unwilling to let go & 0 & 0 \\
\hline Unwilling to let go & $1-49$ & 25 \\
\hline Neither willing or unwilling to let go (indifferent) & 50 & 50 \\
\hline Willing to let go & $51-99$ & 75 \\
\hline Totally willing to let go & 100 & 100 \\
\hline
\end{tabular}

Table 2. Statistics of the Overall Descriptive Sample and Simple Correlation

\begin{tabular}{|l|c|c|c|c|c|}
\hline \multicolumn{1}{|c|}{ Variable } & Mean & Std. Dev. & Minimum & Maximum & Corr $\left(\boldsymbol{Y} ; \boldsymbol{X}_{\boldsymbol{i}}\right)$ \\
\hline Willingness to let go & 55.18 & 37.32 & 0 & 100 & \\
\hline Age of owner & 58.97 & 8.28 & 35 & 81 & 0.46 \\
\hline Age of potential successor & 30.57 & 12.37 & 16 & 65 & 0.50 \\
\hline No of potential successors & 4.02 & 1.89 & 1 & 7 & 0.70 \\
\hline $\begin{array}{l}\text { No of years incumbent is in } \\
\text { Business }\end{array}$ & 23.33 & 12.07 & 8 & 55 & 0.65 \\
\hline $\begin{array}{l}\text { Willingness of potential } \\
\text { successor to step in }\end{array}$ & 26.91 & 41.18 & 0 & 100 & 0.09 \\
\hline $\begin{array}{l}\text { Education level of potential } \\
\text { successor (yrs of schooling) }\end{array}$ & 13.68 & 2.83 & 10 & 18 & -0.37 \\
\hline Ratio of debt to equity & 34.50 & 23.82 & 1 & 92 & -0.52 \\
\hline
\end{tabular}

Table 3. Findings Using Limdep Software

\begin{tabular}{|l|c|c|}
\hline \multicolumn{1}{|c|}{ Variable } & Estimated Coefficients & Marginal Effects \\
\hline Intercept & $\begin{array}{c}49.772 \\
(26.187)\end{array}$ & 48.399 \\
\hline Age Owner & $\begin{array}{c}-0.431 \\
(0.375)\end{array}$ & -0.419 \\
\hline Age of the potential successor & $\begin{array}{c}-1.087^{*} \\
(0.284)\end{array}$ & -1.057 \\
\hline No of competent successors & $\begin{array}{l}13.788^{*} \\
(1.823)\end{array}$ & 13.408 \\
\hline No of years incumbent is in business & $\begin{array}{l}1.358^{*} \\
(0.227)\end{array}$ & 1.320 \\
\hline Willingness of the successor to step in & $\begin{array}{l}-0.128^{*} \\
(0.049)\end{array}$ & -0.124 \\
\hline Education level of successor & $\begin{array}{c}-0.576 \\
(0.847)\end{array}$ & -0.560 \\
\hline Debt to Equity ratio & $\begin{array}{c}-0.434^{*} \\
(0.113)\end{array}$ & -0.422 \\
\hline Log Likelihood & -893.018 & \\
\hline
\end{tabular}

* Asterisks indicate significance at the 0.05 probability level. The values in parentheses are standard errors. 